\title{
Internal Migration and Technological Development ${ }^{1}$
}

\section{KARI HIETALA}

\section{Research Associate}

The Helsinki Research Institute

for Business Economics

Internal migration research as well as internal migration have been a long tradition in Finland. The first migration researcher, J. W. Rosenberg published his doctoral thesis "Om Fattigdomen" (On Poverty) in $1858 .{ }^{2}$ O. K. Kilpi and A. E. Tudeer were among the migration researchers of the early $1900 \mathrm{~s}$. The latest doctoral theses covering internal migration in the whole country were issued by Reino Lento (1951) and Tapani Purola (1964). ${ }^{3}$

In the 1970 s internal migration research has been left in the shadow of emigration research, which has been more extensive. Emigration behaved unexpectedly by manifesting an alarming growth. For this reason great need for information pertaining to emigration was felt. At the same time internal migration showed stable trend and cyclical behavior. Even though, studies on internal migration more concise in their problem settig and their spatial or time dimension have been carried out.

This paper intends to give an over-all view of internal migration. Internal migration will be connected theoretically and empirically to the economic longterm background processes which ultimately are its cause. This examination has a time-span from the mid-1800s to the present day and also considers future prospects. It will be limited to Finland.

\section{On the economic theory of internal migration}

Internal migration is primarily a phenomenon on the local level, but its causes and background factors are also connected to the macro-, enterprise and individual levels as shown in Figure 1 (p. 42).

1 A more extensive version of this article has been published in Finnish in volume »Demografian jatkokoulutusseminaari 1978», Publication No. 5 of the Finnish Population Society, Helsinki 1979.

2 Paloposki, Toivo J.: »Asua aloillaan, olla oloillaan». Muuttoliike ja yhteiskunnan arvostukset in volume "Muuttuvan paikallisyhteisön historia», Publication No. 1 of the Bureau of Local History, Helsinki 1974, p. 67.

3 Lehto, Reino: Maassamuutto ja siihen vaikuttaneet tekijät Suomessa vuosina 1878-1939, Helsinki 1951.

Purola, Tapani: Maassamuuton vilkkaus, Porvoo-Helsinki 1964. 
The central background factor of internal migration on the macrolevel is the growth of productivity, which is related to economic growth and which is manifested among other things by a change in the economic structure. The growth of productivity has been strongest in primary production and in manufacturing. Moreover, as the demand in the former is inflexible, labor force is decreased. However, the demand in manufacturing is more flexible, therefore it is more capable of preserving its share of the labor force. In the service industries, the growth of productivity is slow and the demand flexible; therefore, the labor force increases strongly in this branch of the economy. ${ }^{4}$

The change in the economic structure can be divided into the following stages: $:^{5}$ the agrarian society stage, the accumulating stage, the expanding stage and the society of a new international division of labor and services.

Stage I: The agrarian society stage

Initially the location of farms is determined by one input factor: the availability of land. The landless population moves short distances from one farm to another in search of suitable jobs. ${ }^{6}$ On the other hand, the migration movement may be related to land-clearing activity.

Stage II: The accumulating stage 7

New industry in urban areas or in the proximity of raw material sources is born primarily on the basis of foreign know-how. At the same time, the

4 For more information, see Hietala, Kari: The Economic Causes and Consequences of Emigration. In Migration Research in Scandinavia. Proceedings on Migration Research held at Siikaranta, Finland, in January 3-5, 1973. Ministry of Labor, Planning Division Migration Report 1. Helsinki 1973, pp. 182-187.

5 The first stage theory on the change of the economic structure was presented by A.G.B. Fisher from New Zealand. Later theories such as the theory of Rostow and the one presented here in relation to migration are primarily based on the Fisher theory. The stage theories, especially the Rostow theory, have been criticized, because the stages do not succeed one after another automatically and they are not identical in all countries. In this paper the development in Finland is described and explained. If the variables included in this examination had had different values (for instance motives, values or the speed at which foreign technology is adopted had been different), the speed and the direction of development could have been different. The examination of stage theory presented here is not intended to be deterministic. cf. Fisher, Allan G.B.: The Economic Implications of Material Progress, International Labour Review, Vol. XXXII, Geneva 1935; Rostow, W.W.: The Stages of Economic Growth, Cambridge 1960.

6 Rosenberg, Antti: Muuttoliike Uudenmaan läänissä esi-industrialistisen kauden lopulla 1821-1880. Historiallisia tutkimuksia LXX, published by Suomen Historiallinen Seura, Helsinki 1966, p. 58.

7 Cf. Myrdal, Gunnar: Economic Theory and Under-Developed Regions, London 1957; Pred, Allan: The External Relations of Cities during "Industrial Revolution» 
infrastructure is being constructed actively for the needs of the developing industry. Labor force from the rural areas will move to the jobs thus opening up in industry and construction activity. The primary jobs offered by industry and construction activity will give birth to subsequent jobs in the service industries, which also draw labor force from the rural areas. The urbanization process connected with the change in the economic structure has begun. Especially young people living in rural areas come to find that there is not enough work for them on their home farms and/or no other suitable work is available in their own municipality. Both the jobs and the population are concentrated in urban areas. The net migration will grow proportionally with the size of the urban area, so that especially the largest urban areas will expand.

Stage III: The beginning of the expanding stage

The growth of productivity, the change in the economic structure and urbanization create certain countereffects. As a-result of urbanization, as purchasing power and demand are concentrated, the prices will rise of input factors with an inflexible local supply. The price of land especially will then rise. Enterprises requiring much space will find it profitable to move outside the agglomerations. As an exogenous factor, the regional policy practised by the government will enter in the picture. Attempts may be made to attract investments to the areas of departure. As a result of the growth in productivity, the labor force specializes, the level of education rises, and it will be more heterogenous. This will lead to a situaton where job vacancies corresponding to professional skill or vacancies leading to professional advancement are not necessarily available in the same region. Professional advancement may also mean moving to smaller centers. Furthermore, environmental reasons will emerge as motives. Outside the urban centers there is more room to live, it is quieter, less polluted, nature is more close at hand and living costs are lower. The growth in productivity will gradually lead also to the development of the social security system. This system partly abates migration, ${ }^{8}$ as in our society with an advanced social security system the lack of suitable jobs does not any more present the same physical need to migrate as previously.

Chicago 1962, pp. 55-68; Hägerstrand, Torsten: Urbaniseringen, Lund 1970; Pred, Allan R.: The Growth and Development of Systems of Cities in Advanced Economies, in volume Pred-Törnqvist: Systems of Cities and Information Flows, Lund 1973, pp. 47-55; Ohngren, Bo: Urbanization and Social Change, Four $\gg$ A Themes, Seventh International Economic History Congress, Edinburgh 1978, pp. 75-79.

8 In the recent discussion on labor market policy in Scandinavia attention has been paid to the decrease of labor force mobility. According to Rehn it is due to the strength- 
The change of the economic structure and urbanization will be discontinued or noticeably slowed down after the »excess population» has left primary production. The labor force in primary production is reduced at this point to the level implicated by demand and productivity. ${ }^{9}$ The volume of the labor force in primary production depends on the given exogenous fact: on the level of technology and still more on the endogenous facts: on farm size and the degree of independence which can, to a certain degree, be influenced by the government.

In the case of an open economy and low productivity, without governmental interference, the pressure towards out-migration may continue to a level of extremely low independence. Correspondingly stage IV would be reached at a much later time.

In stage IV environmental factors and reasons related to occupational advancement become the central motives for migration, assuming that the labor force demand is sufficient. However, there are no guarantees for this, as structural change moves from the interindustrial level to the intraindustrial level.

Stage V: The society of a new international division of work and services

Ultimately the impact of global expansion forces the industry of developed countries into an accomodating process, which leads to the final stage of

ening of the ties between employees and enterprises after the Japanese model, to the growing participation of women in the labor force, to the fact that people live more and more in separate houses of their own, to high marginal taxes, which keep the increasing impact of mobility on real income on a low level. Rehn, Gösta: Framtidens arbetsmarknadspolitik, Institutet för Socialforskning, Särtrycksserie nr 20, 1977, p. 3.

The growing differentiation of the labor force and segmentation of the labor market as decreasing factors in mobility have been emphasized in a study conducted by Tor Rødseth: Arbeidsmarkedspolitikken. Mål og midler, Nordiska ministerrådets sekretariat i Oslo, NU A 1978: 1, pp. 151-164.

9 Let the production function be $Q=a L$, where $Q=$ output (= demand) in primary production, $\mathrm{L}=$ labor force in primary production, $\mathrm{a}=$ productivity in primary production.

In a closed economy $Q=Q^{\text {indep. }}=$ volume of domestic consumption, volume of independent production. $\mathrm{a}=\mathrm{a}^{*}=\mathrm{a}$ constant, exogenously dependent on the technological level and, on the other hand, on farm size. Here $L=L^{*}=$ the labor force volume required in primary production that is $\mathrm{L}^{*}=\frac{\mathrm{Q}^{\text {indep. }}}{\mathrm{a}^{*}}$.

Farm size has an inverse effect through productivity on the labor force required in agriculture. In an open economy $Q$ can be greater or smaller than $Q^{i n d e p . ~ a n d ~ c o r-~}$ respondingly $\mathrm{L}>$ or $<$ than $\mathrm{L}^{*}$. If $\mathrm{a}^{*}$ is low, $\mathrm{L}^{*}$ is high, but due to foreign competition 
structural change.10 The large industrial countries specialize in know-howintensive standard products made in long series. The populous developing countries specialize, at least for a while, in less know-how-intensive standard products that are made in long series, although these countries are, in principle, unfavourably disposed towards such a trend. The necessary know-how-intensive parts are purchased as components from the developed countries. The small industrial countries, again, specialize in know-how-intensive non-standard products made in short series or by special order and also in know-how-intensive components. All countries are striving to develop small-scale industry based on local taste, fashion and traditions and which also exports its products, in order to secure domestic jobs. ${ }^{11}$ In practice, however, the division of labor is not so distinct, as enterprises are able to influence their area of activity by means of international operations. Thus the internationalization of enterprises may supplant the division of labor.

Moreover, the situation will change rapidly along with technological development. New products will be a major field of competition. In addition, the flexibility of resources will become a central competitive factor. The ability to innovate and the mobility of the labor force and of other resources will be the decisive factors affecting the standard of living and employment and, consequently, also the migration movement.

It appears that the significance of labor force mobility will grow in the future, although the traditional form of mobility, migrating from the rural areas to the urban areas, will cease. The focus will probably be found in occupational mobility. A sufficiently broad level of basic education would facilitate this trend.

\section{The size, variation and direction of internal migration}

Annual internal migratory statistics were first drawn up in Finland in 1878, at the very beginning of the industrialization and accumulating process. Only case-information laborious to attain is available on earlier mobility.

the degree of independence tends to decrease without government interference, so that $\mathrm{Q}$ and $\mathrm{L}$ are low. In the case of high productivity (a is great), $\mathrm{L}$ is small, but it may also become "great", that is $\mathrm{L}>\mathrm{L}^{*}$, if due to high productivity a sufficient amount of exports capable of competition has been reached. Examples of this are Denmark, the United States and Canada.

10 The assessments of the future presented here are derived mainly from the socalled product cycle-theory, which was originally presented in the article: Vernon, Raymond: International Investment and International Trade in the Product Cycle, Quarterly Journal of Economics, May 1966, pp. 160-207.

11 According to Mukherjee this »domestic sector» would consist of small enterprises of the cottage and handicraft industry type, where the wage level would be lower than 
The variation of the internal migratory series can be divided into three components: the trend, "normal» business cycle change and special variation. ${ }^{12}$

The trend

In $1881-85$ the internal migration rate was on the average 42281 persons per year, that is $2 \%$ of the population. In $1971-75$ internal migration was 233611 persons per year, that is $5 \%$ of the population. Thus internal migration had increased during the statistical period of 90 years by 5.5 times absolutely and by 2.5 times in proportion to the population. According to the calculated trend internal migration in proportion to the population has increased 0.18 percentage points per 5-year-period on the average, that is 0.036 percentage points per year. ${ }^{13}$ The trend explicates, when the business cycle component is standardized, $78 \%$ of the migratory variation, that is most of it. The porportion of the special variation, the other two components being standardized, remains thus at $22 \%$.

Behind the rising trend are the following background factors which have increased mobility:

- The proportion of the static, landowning farm population (farmers, farmowners) has diminished constantly along with the structural change. ${ }^{14}$ The agrarian society stage lasted a rather long time in Finland considering the level of development, due partly to the settlement of population removed from the territory surrendered to the Soviet Union in 1944; the settlement of Lappland continued till the 1950s. The disengagement from primary industry then proceeded unusually rapidly. The number of those engaged in primary production decreased in the sixties in Finland twice as much $(14 \%)$ as in other Nordic countries $(7 \%)$.

in the competitive sector, but this would be compensated for by certain immaterial benefits. Mukherjee, Santosh: On Alternative Strategies and Instruments: What is to be done about unemployment?, paper presented at a Nordic Conference on Labor Policy in Denmark 24.-27. 10. 1978.

12 These components can be studied in appendices I and II. Appendix I shows the cyclical variation of internal migration when the other two components have not been standardized. Appendix II shows the trend and (with a longer effect) the special variation, when the other components have been standardized. The sdeviations from the trend" presented in appendix II can be explained as special variations when the »normal business cycle is assumed to have a length of 5 years, that is the observation period and the cycles are assumed to be identical. Without the special variation, deviations from the trend would in this case be zero.

13 The observed trend would rise even more steeply, if the internal migratory series would be rectified by the diminishing effect of the decrease in the number of municipalities (growth in municipality size) on intermunicipal migration.

14 See, Purola, Tapani: Maassamuuton vilkkaus, Porvoo-Helsinki 1964, pp. 97-98. 
- Communication and information regarding the area of destination have improved along with the development of technology; mobility has become easier, transportation faster and less expensive.

- The accumulating stage has included self-reinforcing feed-back effects which accelerated the process.

- With the diversification of the labor force, it has become more and more often necessary to migrate in order to gain advancement in one's occupation (cf. the migration of journeymen, apprentices and civil servants in the preindustrial period).

- The mobility of the labor force has also been encouraged (the development of the State employment service, relief measures for mobility).

The influence of the above mentioned background factors in increasing mobility is most likely to diminish in the future. The agricultural labor force reserve will be exhausted. There will be no more room for improvement in the level of information on job opportunities in the destination areas after the State employment bureaus change over to the real time system in job vacancies. There will be growth of expansion effects, which will, in fact, encourage mobility. In addition, Finland is bound to face the same factors decreasing migration found in Sweden. ${ }^{15}$ Ultimately, however, internal migration will depend on the impact of the various stages of future structural development on the regional distribution of jobs.

\section{Special variation}

The largest deviations from the trend are as follows:

- In the 1920 s mobility was low. Internal migration was $23 \%$ lower than the calculated trend value. Migration in proportion to the population remained on the level of the late 1800 s until 1930.

- In the $1930 \mathrm{~s}$ mobility was high. In $1931-35$ internal migration was $25 \%$, that is a quarter higher than presupposed by the trend.

- At the end of the 1940 s, in the post-war period, internal migration peaked. In $1946-50$ the annual internal migration was $5.5 \%$ of the population, which was more than in the early 1970 s. Migration was at that time $34 \%$ higher than the calculated trend.

Behind these exceptional periods the following reasons can be distinguished. The growth of mobility at the end of the 1920 s and the beginning of the 1930 s was artificial to a great extent. The size of the fine paid for unmade transfer declarations, devalued by inflation, was raised in 1931, when migration from the 1920 s was registered for this year. The amount of migrants rose to more than three times its previous size in one year, in spite of the prevailing serious de-

15 Rehn, Gösta: cf. foot note 6. 
pression. Similarly, the low level of migration in the 1920 s was artificial to a great extent. ${ }^{16}$

The fairly low level of mobility in the late 1920 s and in the early 1930 s considering the point in time, can be explained by the marked emigration to America at the beginning of the century, by the decrease in farm workers who previously had been very mobile and by the diminished growth of the labor force demand in an economic system heading towards depression. The male and female farm help had largely migrated from rural villages to urban centers in the early 1900 s, as indicated in a study on internal migration within certain municipalities. ${ }^{17}$ On the other hand, disengagement of the farm owners from agriculture had not yet begun to any noticeable degree, because productivity was still growing slowly.

A real growth in pressure to migrate was caused by the serious international depression of the early 1930s, the lagged effect of which was probably reflected in the internal migration of the end of the decade, when the labor force demand slowly began to revive. The growth of the labor force demand from outside the municipality obviously was influenced by the decline in urban fertility that began in the 1910 s and reduced the growth of the local labor force supply. 18 In this regard, the high internal migration in the late 1930 s appears to have a normal, business cycle background characteristic of the accumulating stage. - The significance of the above mentioned factors should not be overestimated, as the deviations from the trend are very slight after the rectifications have been made.

Also part of the extremely high mobility of the late 1940 s was artificial. The in-migrants from areas ceded to the Soviet Union, may have made declarations of migration even if they had actually migrated earlier. ${ }^{19}$

The real growth of internal migration in the late 1940 s can be summarized as follows. The internal migration typical of the early agrarian society and of

16 Lento, Reino: Maassamuutto ja siihen vaikuttaneet tekijät Suomessa vuosina 1878-1939, Helsinki 1951, pp. 28-31 and Ranta, Raimo: Muuttoliike kaupunkeihin. Muuttuvan paikallisyhteisön historia, Paikallishistoriallisen toimiston julkaisuja no. 1. Helsinki 1974 , p. 83.

The matter can be demonstrated by the following calculations. Instead of the statistical figure 313505 , it can be assumed that the in-migration to the municipalities was on the same level in 1931 as in the following year 1932, which was also a year of serious depression, and the amount of in-migration was 101720 . Consequently the figures for 1931 include approximately 200000 persons who had actually in-migrated in the $1920 \mathrm{~s}$. If they are distributed equally for the $1920 \mathrm{~s}$, the deviation decreases $-2-$ $(-3) \%$ from the trend in $1921-30$. Likewise, the real deviation from the trend is approximately $-2 \%$ in $1931-35$, which means that in-migration was slightly below the trend, due to the depression. - The above mentioned rectifications would increase the explaining power of the trend to $84 \%$.

17 Laakso, Veikko: Kunnan sisäinen muuttoliike. Muuttuvan paikallisyhteisön historia. Paikallishistoriallisen toimiston julkaisuja no 1, Helsinki 1974, p. 76.

18 Lento, cf. p. 90.

19 Ranta, cf. p. 83. 
the accumulating stage coincided atypically at this time. During the period in question the settling of the evacuees and the veterans occurred, even though land-clearing migration is usually characteristic of the agrarian society. In addition, industrialization and building activity were considerable due to reconstruction and to the war indemnities. Thus behind the migratory boom in the late 1940 s was the war.

A special variation in the time series of internal migration different from the trend and from "normal» business cycles is thus due to the sporadic postponement of the transfer declarations, to the war and to exceptional factors affecting the labor force supply and demand. These factors are partly in close connection with the structural change process (decline of urban fertility, structural changes among those working in agriculture); partly they are exogenous factors (the depression in the early 1930s).

\section{Business cycle fluctuation}

When the exceptional post-war situation was left behind, internal migration grew steadily from the year 1951 on. It was at its highest during the boom years $1955,1960,1964-65,1970$ and 1974 .

The variations closely connected to business cycles are caused by the fact that people have migrated to the areas of arrival only if vacant jobs have been available, i.e. job vacancies have been a prerequisite for migration. Moreover, there have always been more than enough applicants for the job vacancies, i.e. a labor force oversupply has been prevalent (a lack of labor force demand). The pressure towards migration has thus been greater than the availability of job vacancies for the in-migrants.

In addition to business cycle factors, pressure towards migration is affected, among other factors, by the arrival on the labor market of the large age classes born after the war, and by the rapidity with which the labor force has disengaged itself from primary production. These factors have influenced the variations of international migration, but not of the internal migration. ${ }^{20}$ Internal migration has depended exclusively on the business-cyclelinked overdemand of labor force (job vacancies), with certain factors (housing production, emigration to Sweden) completing the picture.

The fact that job vacancies have become a dominant regulator of internal migration is probably due to the development of the social and unemployment

20 Hietala, Kari: Migration Flows between the Nordic countries in 1963-1975. An Econometric Analysis of the Factors behind them, in volume: Finnish Contributions to the IUSSP Conference on Economic and Demographic Change: Issues for the 1980's, Publications of the Demographic Society in Finland, No. 4, Helsinki 1978, pp. 46-49. Published also in volume: Economic and Demographic Change: Issues for the 1980's. Proceedings of the conference, Helsinki 1978, Vol. 3, Liège 1979. 
security services. If no physical need exists for migration, migration is not worthwhile before a job has been secured.

The internal migration connected with the accumulating stage (migration to urban areas) is more vulnerable to business cycles effects; than the migration connected with the expanding stage (migration to the rural areas) as Appendix I shows. It revealed a growth of migration to urban municipalities from 1978 to 1979 by $7.8 \%$ and to rural municipalities by $3,5 \%$. Thus the beginning rise in the business cycle increased the migration of the accumulating stage twice more than that of the expanding stage. In 1979 urban centers showed a small migration surplus. Analogously, when a depression comes migration to the urban areas will probably decline relatively more than migration to the rural areas.

The direction of internal migration

An examination by the form of municipality makes it possible to draw up certain conclusions about the stage to which migration is related.

The migration to rural municipalities remained constant between the boom years of $1955-74$, while the migration to urban municipalities more than doubled. The accumulating stage has thus dominated. On the other hand, expanding stage is indicated by the fact that migration from the urban areas has grown more rapidly, almost threefold. In 1977 the urban areas finally suffered from net out-migration and the rural municipalities consequently had net in-migration. If this is not related to the exceptional business cycle situation, it can be said that the expansion impact in 1977 surpassed the accumulation impact for the first time since industrialization began a hundred years ago. The rural areas did have net in-migration in 1918, but this was related to a very abnormal situation.

If the expansion impact included migration from Helsinki to the surrounding urban municipalities (environmental motives), based more often on the distribution of dwellings than of job vacancies, the expansion impact would have become a dominant component of migration already at an earlier stage. Part of the rest of the increased interurban migration can be explained as well by means of motives connected with the expanding stage (occupational advancement, decentralization of jobs).

\section{Internal migration seen through time series-analysis}

Table 1 (p. 43) presents the dependence of internal migration on certain background factors estimated from time series-data. Internal migration is explained by factors connected to the employment situation in Finland $\left(V^{F}\right.$ and $U^{F}$ ), by the business cycle and growth indicator (GNP), housing production $(\mathrm{H})$, the trend 
(T) and by the alternative offered by emigration to Sweden $\left(\mathrm{M}^{\mathrm{FS}}\right.$ and $\left.\mathrm{V}^{\mathrm{F}}\right)$; $\mathrm{t}-$ values are indicated in parentheses below the regression coefficients.

It can be seen that business cycle/growth factors (Model 1), the employment situation in Finland (Model 2) and housing production (Model 3) all have, when measured separately, a significant impact on internal migration. The elasticity corresponding with the GNP coefficient and calculated by the mean value method is .250 . Consequently when the GNP increases by $1 \%$, internal migration grows by $.25 \%$. When the number of job vacancies increases by 1 , internal migration grows by 3.45 persons, that is when job vacancies grow by $1 \%$, internal migration grows by $.213 \%$. When unemployment increases by 100 , internal migration decreases the following year by 36 (elasticity is .001); the obtained low coefficient does not show a statistically significant deviation from zero. When finally the number of produced dwellings grows by 100 , the growth of internal migration is 163 persons (elasticity is .309).

The increasing effect of job vacancies on the marginal propensity to migrate is due to the fact that only a part of the in-migrants belong to the labor force and that only a part of the jobs actually available have been registered. ${ }^{21}$ On the other hand, the coefficient of the produced dwellings is increased because the migrating households include more than one person on the average. If the average size of the migrating household were 1,6 person, the marginal propensity to migrate connected with the produced dwellings would be 1 per household, that is one household per produced dwelling would always in-migrate to the municipality. In this case in-migration would not affect housing density of original population.

The job vacancies available in Finland have under certain presumptions a threefold marginal effect on internal migration when compared with that of delayed unemployment. The $\mathrm{V}^{\mathrm{F}}$ coefficient rectified by the estimated registration proportion of vacant jobs per $U^{F}$ coefficient is $(1 / 3) 3.45 / .36=3.19$. The greater explicability of migration by the spull» exercised by job vacancies compared with the "push" of the unemployment situation is due to the prevalence of the labor force oversupply. Because of an insufficient labor force demand all the migration pressure has not been released at birth. Part of those who became unemployed during the recession have been forced to wait for the upswing period in order to get a job in the receiving areas. The upswing

21 Let's assume that $\mathrm{M}=a \mathrm{~V}^{\mathrm{F}}$, where $\mathrm{M}=$ internal migration; $\mathrm{V}^{\mathrm{F}}=$ (registered) job vacancies in Finland; $a=$ the marginal propensity to migrate of the job vacancies $\left(a=\partial \mathrm{M} / \partial \mathrm{V}^{\mathrm{F}}\right)$. The above mentioned equation is widening to: $\mathrm{rM}=\mathrm{r} \cdot \mathrm{s} \cdot \mathrm{a} \cdot \frac{1}{\mathrm{~S}} \mathrm{~V}^{\mathrm{F}}$,

where $\mathrm{r}=$ labor force participation of the in-migrants $(0<\mathrm{r}<1)$; $\mathrm{s}=$ proportion of job vacancies registered $(0<\mathrm{s}<1) ; \mathrm{rM}=\mathrm{M}^{\text {labor } \mathrm{f}}$. $=$ in-migrants who belong to the labor force; $(1 / \mathrm{s}) \mathrm{V}^{\mathrm{F}}=\mathrm{V}^{\mathrm{F}}$.act. $=$ actual job vacancies. Thus we have $\partial \mathrm{Mlabor} f$. $/ \partial \mathrm{VS}$.act. $=\mathrm{r} \cdot \mathrm{s} \cdot \mathrm{a}$. If for instance $\mathrm{r}=2 / 3, \mathrm{~s}=1 / 3$ and $\mathrm{a}=3.45$, we have r.s.a $=.767$. Thus three fourths of the actual job vacancies will be filled by the in-migrants (to the municipality) and one third by those already residing in the municipality. As a result work participation is greater in the receiving municipalities than in the sending municipalities. 
period has then permitted more migration, the more the labor force demand has risen. That is why job vacancies explain migration more adequately than unemployment. That is why unemployment has had a lagged impact on migration. That is one reason why Sweden, an alternative destination for migration, has been so popular. The estimated great "pull» is due to the degree of the "push", unreleased emigration pressure, which has been so strong. ${ }^{22}$ As the "pull» is thus a function of the "push", it cannot be said that the "pull» would be greater than the "push" - as has been concluded in some previous migration studies.

The variables GNP, $\mathrm{V}^{\mathrm{F}}$ and $\mathrm{H}$ have a strong mutual correlation. When applied to the same models, they would obtain lower non-significant coefficients due to multicollinearity. The significance level of the $\mathrm{H}$ coefficient drops slightly below the limit of $5 \%$ also under the impact of the trend variable alone. It can be concluded that the lack of dwellings forms a ceiling on migration in certain situations - as does the lack of job vacancies. As such housing production does not encourage internal migration unattached from the rest of the business cycle and structural development, since the standardization of the impact of variables which fluctuate according to business cycles (GNP and $V^{F}$ ) and/or the elimination of the trend make the coefficient non-significant.

Emigration to Sweden obtains a non-significant positive coefficient in models $1-3$. In models 4 and 5 , where the variable of job vacancies in Sweden $\left(\mathrm{V}^{\mathrm{S}}\right)$ is included, emigration obtains a non-significant negative coefficient. Thus $\mathrm{M}^{\mathrm{FS}}$ functions as a substitute variable for $\mathrm{V}^{\mathrm{S}}$ in models $1-3$. Emigration compensates for internal migration according to models 4 and 5, when the impact of vacant jobs in Sweden has been standardized. Job openings in Sweden obviously function in the model as an indicator of international business cycle development. During the boom period, among other things, the number of job vacancies in Sweden increases, as do emigration to Sweden and exports from Finland to Sweden. The latter factor increases the labor force demand and internal migration in Finland. That is why $\mathrm{V}^{\mathrm{S}}$ has a positive impact on internal migration in Finland.

The coefficient -.83 of model 5 can be considered a real impact of emigration compensating for internal migration, because then the impact of the business cycle/employment situation is standardized both in Finland and in Sweden. When emigration increases by 100 , internal migration decreases ceteris paribus by 83 persons. It can be demonstrated that internal migration compensates correspondingly for emigration. As internal migration decreases, emigration increases. However, these compensating effects are statistically non-significant.

The time series-models examined above can be applied when examining

22 See the study: Hietala, Kari: Muuttoliike ja epätäydelliset työvoimamarkkinat. Ekonometrinen tutkimus Suomen ja Ruotsin välisestä siirtolaisuudesta sekä siihen vaikuttavista tekijöistä. Työvoimaministeriö, Suunnitteluosasto, Siirtolaisuustutkimuksia No. 16, Helsinki 1980. 
whether the decline in internal migration after 1974 is of a business cycle nature (worse employment situation) or whether the decline is permanent. The matter was studied by means of model 2. A calculation was made of how much variation was caused in internal migration by the observed change in job vacancies and in unemployment (lagged by one year) since the year 1974. The partial effects of job vacancies and unemployment were added together and reduced from the size of internal migration in 1974 . The following values were obtained:

Internal migration

$\begin{array}{rrrrr}\text { year } & \text { Calculated } & \text { Actual } & \text { Absolute } & \% \\ 1977 & 190.016 & 188.687 & 1.329 & 0,70 \\ 1978 & 180.853 & 180.804 & 49 & 0,03 \\ 1979 & 183.562 & 191.774 & -8.212 & -4,28\end{array}$

It can be noted that the deterioration in the employment situation entirely explains the decline of internal migration in the late 1970s. The declining trend of internal migration has thus been purely of a business cycle nature, and was dependent on the prevailing depression. When the rise in the business cycle began in 1979, internal migration grew immediately, even slightly more than the improved employment situation would have implied according to previous development. In spite of the prevailing boom, internal migration has remained distinctly below the level of previous boom years, because the employment situation is now worse.

\section{Prospects of internal migration}

The decline of internal migration in the late 1970 s was occasioned merely by the weakened employment situation - not by the diminution of the propensity to migrate. The propensity to migrate will apparently show a declining tendency perhaps already in the 1980 s. This phenomenon has already taken place in the other Nordic countries - especially in Sweden. Factors that have evenly increased mobility are losing their significance in Finland also. Thus, low mobility will probably become a problem in the future, as the new situation of international competition implies great flexibility and mobility. Economic growth and the presumed decline in the propensity to migrate will most likely come in conflict in the future.

In the other Nordic countries the decreased mobility of the labor force which is still continually dropping will cause pressure towards emigration. It is obvious that emigration from Finland will increasingly compensate for the diminished mobility of the labor force of Sweden and Norway, especially. Thus, the problem of mobility is of common interest to the Nordic countries.

Up till now, accumulating and expanding effects have dominated internal migration. Since these tendencies are now roughly in balance, individual life 
and occupational cycles will probably become central background factors for migration flows. Migration will also be more often motivated by environmental and leisure time factors.

Values and the regional policy practiced has couraged and continue to encourage the expanding impact. Environmental factors are taken increasingly into consideration. Even various national movements have been started for this purpose. Rural living surroundings are valued. On the other hand, regional policy has created new job vacancies in old areas of departure, which strengthens the parallel tendency automatically caused by the marketing mechanism. The expanding impact would hardly be powerful enough alone to balance the accumulating tendency without the strengthening influence of values and regional policy.

How the expanding impact will continue depends primarily on the ability to create new job vacancies in the rural and developing areas in labor-intensive small and medium-size industry. Primary production will probably be unable to decisively increase the number of jobs, since the growth of productivity has not been maximized, for instance due to small farm size (cf. footnote 8). The service industries require a certain population base. Jobs in large industries are decreasing due to rationalization and the existing large industries will not be likely to increase their labor force demand. It is also rather unlikely that new large industries will be established in the developing areas, because the existing large industries are based on local rawmaterials, which are already being used to a great extent.

The size and the direction of internal migration have been mainly determined by the structural change caused by technological development. A minor effect on migration has been imposed by the guiding of labor force mobility. In addition, attitudes towards the guiding of the labor force have been contradictory. Interest-groups supported by areas of departure oppose the longdistance mobility of the labor force. ${ }^{23}$ Then again, political groups whose major support comes from the receiving areas support long-distance migration also. Attitudes towards migration have thus partly become a way to compete for voters. It is naturally not possible on this basis to face future challenges and to create the necessary long-term migration policy. The government has become all the more powerless as a regulator of migration. The same situation seems to continue when proceeding to the $\mathrm{V}$ stage of our stage theory, to the "society of a new international division of labor and services». A revaluation of internal migration on the basis of the long-term trend presented in this article is needed. The present state and the future prospects of internal migration should be seen as a part of historical evolution.

23 Long-distance mobility here means mobility between economic regions, i.e. migration from the developing regions to Southern Finland. Local migration here means migration within an economic region. The economic regions are provinces or similar regional entities. 
Figure 1. Connections of internal migration with systems on macro, enterprise, individual and regional levels.

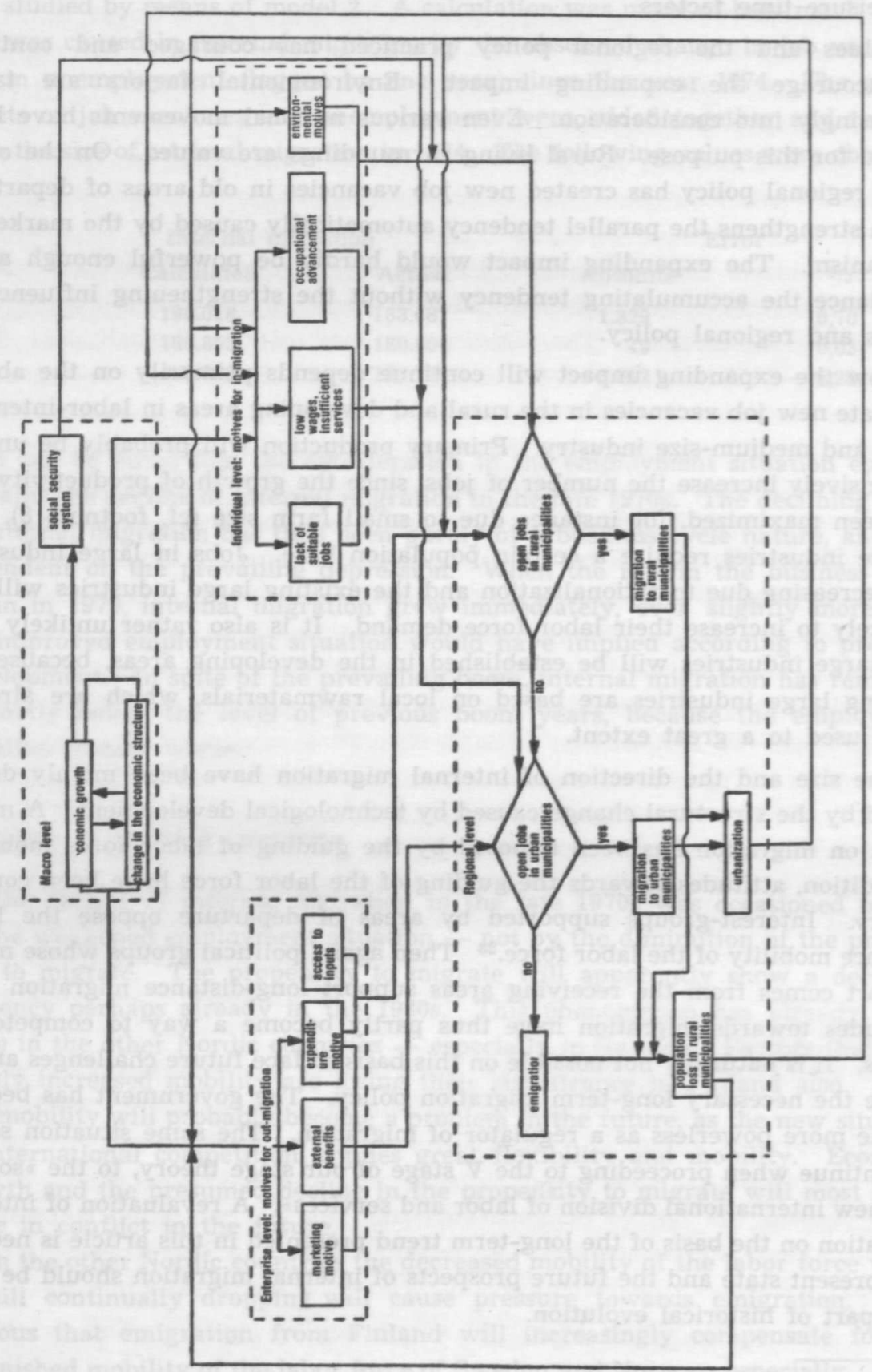




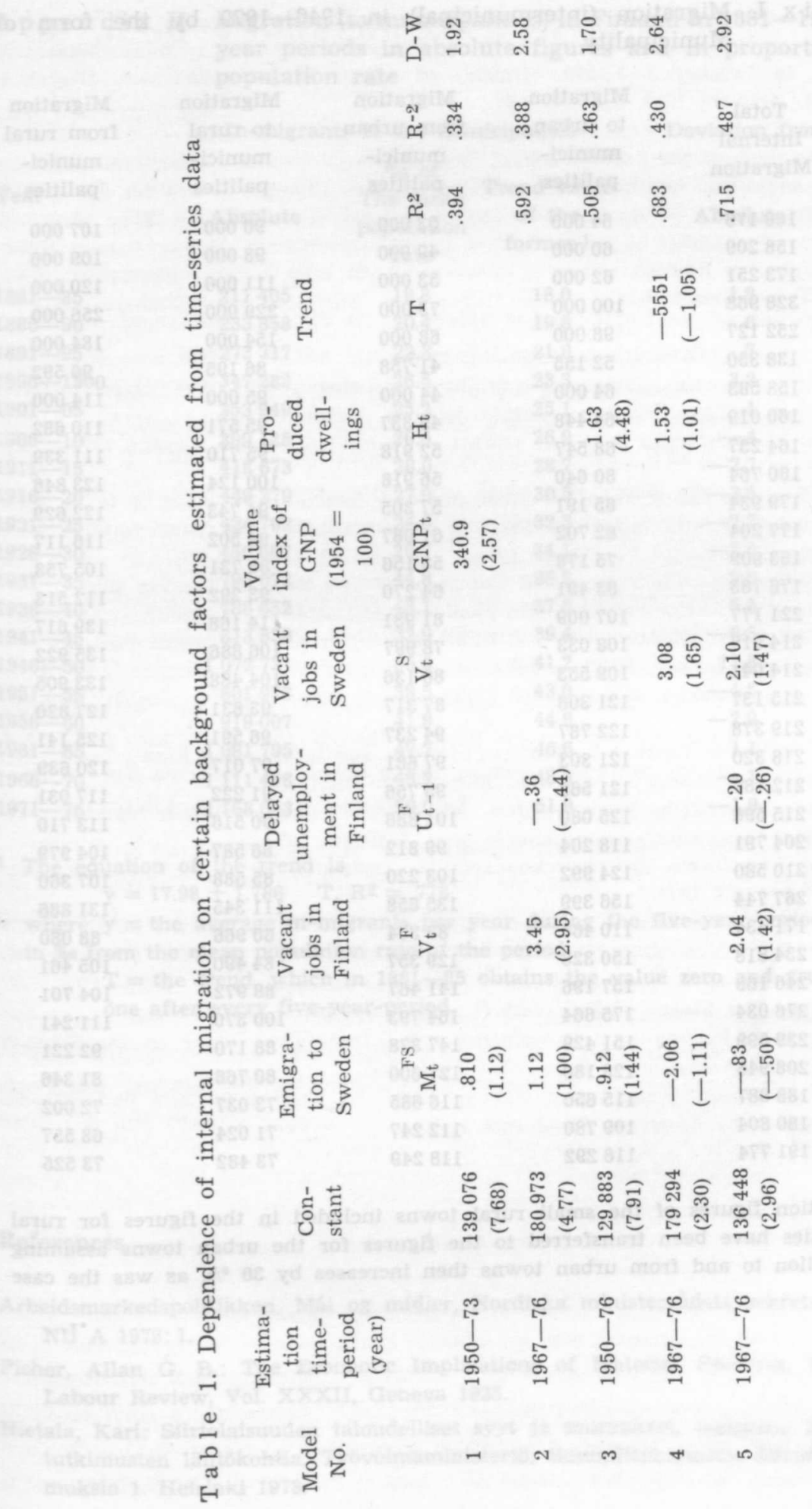


A ppendix I. Migration (intermunicipal) in $1946-1979$ by the form of Municipality

\begin{tabular}{|c|c|c|c|c|c|}
\hline Year & $\begin{array}{c}\text { Total } \\
\text { Internal } \\
\text { Migration }\end{array}$ & $\begin{array}{l}\text { Migration } \\
\text { to urban } \\
\text { munici- } \\
\text { palities }\end{array}$ & $\begin{array}{l}\text { Migration } \\
\text { from urban } \\
\text { munici- } \\
\text { palities }\end{array}$ & $\begin{array}{l}\text { Migration } \\
\text { to rural } \\
\text { munici- } \\
\text { palities }\end{array}$ & $\begin{array}{l}\text { Migration } \\
\text { from rural } \\
\text { munici- } \\
\text { palities }\end{array}$ \\
\hline 19461 & 160176 & 64000 & 53000 & 96000 & 107000 \\
\hline 19471 & 158209 & 60000 & 49000 & 98000 & 109000 \\
\hline 19481 & 173251 & 62000 & 53000 & 111000 & 120000 \\
\hline 19491 & 328968 & 100000 & 73000 & 229000 & 256000 \\
\hline $1950^{1}$ & 252127 & 98000 & 68000 & 154000 & 184000 \\
\hline 1951 & 138350 & 52155 & 41758 & 86195 & 96592 \\
\hline 19521 & 158583 & 64000 & 44000 & 95000 & 114000 \\
\hline 1953 & 160019 & 64448 & 49337 & 95571 & 110682 \\
\hline 1954 & 164257 & 68547 & 52918 & 95710 & 111339 \\
\hline 1955 & 180764 & 80640 & 56918 & 100124 & 123846 \\
\hline 1956 & 179934 & 85191 & 57305 & 94743 & 122629 \\
\hline 1957 & 177204 & 82702 & 61087 & 94502 & 116117 \\
\hline 1958 & 163909 & 75178 & 58156 & 88731 & 105753 \\
\hline 1959 & 176783 & 83491 & 64270 & 93292 & 112513 \\
\hline 1960 & 221177 & 107009 & 81931 & 114168 & 139617 \\
\hline 1961 & 214919 & 108033 & 78997 & 106886 & 135922 \\
\hline 1962 & 214041 & 109553 & 80136 & 104488 & 133905 \\
\hline 1963 & 215137 & 121306 & 87317 & 93831 & 127820 \\
\hline 1964 & 219378 & 122787 & 94237 & 96591 & 125141 \\
\hline 1965 & 218320 & 121303 & 97681 & 97017 & 120639 \\
\hline 1966 & 212787 & 121565 & 95756 & 91222 & 117031 \\
\hline 1967 & 215596 & 125080 & 101886 & 90516 & 113710 \\
\hline 1968 & 204791 & 118204 & 99812 & 86587 & 104979 \\
\hline 1969 & 210580 & 124992 & 103220 & 85588 & 107360 \\
\hline 1970 & 267744 & 156399 & 135858 & 111345 & 131886 \\
\hline 1971 & 171434 & 110468 & 83354 & 60966 & 88080 \\
\hline 1972 & 234818 & 150328 & 129357 & 84490 & 105461 \\
\hline 1973 & 246168 & 157196 & 141467 & 88972 & 104701 \\
\hline 1974 & 276034 & 175664 & 164793 & 100370 & 111241 \\
\hline 1975 & 239599 & 151429 & 147378 & 88170 & 92221 \\
\hline 1976 & 208946 & 128180 & 127600 & 80766 & 81346 \\
\hline 1977 & 188687 & 115650 & 116685 & 73037 & 72002 \\
\hline 1978 & 180804 & 109780 & 112247 & 71024 & 68557 \\
\hline 1979 & 191774 & 118292 & 118249 & 73482 & 73525 \\
\hline
\end{tabular}

1 The migration figures of the small rural towns included in the figures for rural municipalities have been transferred to the figures for the urban towns assuming that migration to and from urban towns then increases by $30 \%$, as was the case in 1951. 
A p pendix II. Migration (to municipalities) in Finland in 1881-1975 by five year periods in absolute figures and in proportion to the population rate

In-migrants to the municipalites Deviation from the trend

$\begin{array}{lrrrrr}\text { Year } & \text { Absolute } & \begin{array}{c}\text { \%o of } \\ \text { The mean } \\ \text { population } \\ \text { rate }\end{array} & \begin{array}{c}\text { Trend value } \\ \text { of the } \\ \text { former }\end{array} & \text { Absolute } & \text { \% } \\ 1881-85 & 211405 & 19.8 & 18.0 & 1.8 & 10.0 \\ 1886-90 & 233858 & 20.4 & 19.8 & .6 & 3.0 \\ 1891-95 & 273317 & 22.3 & 21.6 & .7 & 3.2 \\ 1896-1900 & 347282 & 26.5 & 23.3 & 3.2 & 13.7 \\ 1901-05 & 353949 & 25.2 & 25.1 & .1 & .4 \\ 1906-10 & 399125 & 26.5 & 26.9 & -.4 & -1.5 \\ 1911-15 & 418673 & 26.0 & 28.7 & -2.7 & -9.4 \\ 1916-20 & 449279 & 27.0 & 30.5 & -3.5 & -11.5 \\ 1921-25 & 424702 & 24.6 & 32.3 & -7.7 & -23.8 \\ 1926-30 & 450067 & 26.7 & 34.1 & -7.4 & -21.7 \\ 1931-35 & 790072 & 44.8 & 35.8 & 9.0 & 25.1 \\ 1936-40 & 786652 & 43.1 & 37.6 & 5.5 & 14.6 \\ 1941-45 & 613539 & 32.9 & 39.4 & -6.5 & -16.5 \\ 1946-50 & 1072731 & 55.0 & 41.2 & 13.8 & 33.5 \\ 1951-55 & 801973 & 38.5 & 43.0 & -4.5 & -10.5 \\ 1956-60 & 919.007 & 41.9 & 44.8 & -2.9 & -6.5 \\ 1961-65 & 1081795 & 47.7 & 46.6 & 1.1 & 2.4 \\ 1966-70 & 1111498 & 48.2 & 48.3 & -.1 & -.2 \\ 1971-75 & 1168053 & 50.0 & 51.9 & -1.9 & -3.7\end{array}$

1 The equation of the trend is

$$
\mathrm{y}=17.98+1.786 \quad \mathrm{~T}, \mathrm{R}^{2}=.778
$$

where $y=$ the average in-migrants per year during the five-year-period

in $\%$ from the mean population rate of the period

$\mathrm{T}=$ the trend, which in $1881-85$ obtains the value zero and grows then by one after every five-year-period.

\section{References}

Arbeidsmarkedspolitikken. Mål og midler, Nordiska ministerrådets sekreteriat i Oslo, NU A 1978: 1 .

Fisher, Allan G. B.: The Economic Implications of Material Progress, International Labour Review, Vol. XXXII, Geneva 1935.

Hietala, Kari: Siirtolaisuuden taloudelliset syyt ja seuraukset, teoksessa Siirtolaisuustutkimusten lähtökohtia. Työvoimaministeriö, Suunnitteluosasto, Siirtolaisuustutkimuksia 1. Helsinki 1973. 
Hietala, Kari: The Economic Causes and Consequences of Emigration. In Migration Research in Scandinavia. Proceedings on Migration Research held at Siikaranta, Finland, in January 3-5.1973. Ministry of Labor, Planning Division. Migration Report 1. Helsinki 1973, pp. 182-187.

Hietala, Kari: Migration Flows between the Nordic Countries in 1963-1975. An Econometric Analysis of the Factors behind them teoksessa Finnish Countributions to the IUSSP Conference on Economic and Demographic Change: Issues for the 1980's, Publications of the Demographic Society of Finland, no 4, Helsinki 1978.

Hietala, Kari: Muuttoliike ja epätäydelliset työvoimamarkkinat. Ekonometrinen tutkimus Suomen ja Ruotsin välisestä siirtolaisuudesta sekä siihen vaikuttavista tekijöistä. Työvoimaministeriö, Suunnitteluosasto, Siirtolaisuustutkimuksia No. 16. Helsinki 1980.

Hägerstrand, Torsten: Urbaniseringen, Lund 1970.

Laakso, Veikko: Kunnan sisäinen muuttoliike. Muuttuvan paikallisyhteisön historia. Paikallishistoriallisen toimiston julkaisuja no 1, Helsinki 1974.

Lento, Reino: Maassamuutto ja siihen vaikuttavat tekijät Suomessa vuosina 1878-1939, Helsinki 1951.

Mukherjee, Santosh: On Alternative Strategies and Instruments: What is to be done about unemployment?, esitelmä Pohjoismaisessa korkean tason työvoimapoliittisessa kongressissa Tanskassa 24.-27. 10.1978.

Myrdal, Gunnar: Economic Theory and Under-Developed Regions, London 1957.

Paloposki, Toivo J.: »Asua aloillaan, olla oloillaan». Muuttoliike ja yhteiskunnan arvostukset, teoksessa Muuttuvan paikallisyhteisön historia, Paikallishistoriallisen toimiston julkaisuja no 1, Helsinki 1974.

Pred, Allan: The External Relations of Cities during 'Industrial Revolution', Chicago 1962.

Pred, Allan-Törnqvist Gunnar E.: Systems of Cities and Information Flows, Lund 1973.

Purola, Tapani: Maassamuuton vilkkaus, Porvoo-Helsinki 1964.

Ranta, Raimo: Muuttoliike kaupunkeihin. Muuttuvan paikallisyhteisön historia, Paikallishistoriallisen toimiston julkaisuja no 1 , Helsinki 1974.

Rehn, Gösta: Framtidens arbetsmarknadspolitik, Institutet för Socialforskning, Särtrycksserie $\mathrm{nr} 20,1977$.

Rosenberg, Antti: Muuttoliike Uudenmaan läänissä esi-industrialistisen kauden lopulla (1821-1880), Historiallisia tutkimuksia LXX, julkaissut Suomen Historiallinen Seura, Helsinki 1966.

Rostow, W. W.: The Stages of Economic Growth, Cambridge 1960.

Vernon, Raymond: International Investment and International Trade in the Product Cycle. Quarterly Journal of Economics, May 1966.

Ohnngren, Bo: Urbanization and Social Change, Four $\gg A »$ Themes, Seventh International Economic History Congress, Edinburgh 1978. 